\title{
Research advances and challenges in biogeotechnologies
}

Jia He PhD, Meng, BEng

Associate Professor, Key Laboratory of Ministry of Education for Geomechanics and Embankment Engineering, Hohai University, Nanjing, China

Jian Chu PhD, BEng

Professor, School of Civil and Environmental Engineering, Nanyang Technological University, Singapore, Singapore (corresponding author: cjchu@ntu.edu.sg)
Yufeng Gao PhD, MEng, BEng

Professor, Key Laboratory of Ministry of Education for Geomechanics and Embankment Engineering, Hohai University, Nanjing, China

Hanlong Liu PhD, MEng, BEng (Hons)

Professor, School of Civil Engineering, Chongqing University, Chongqing, China

In recent years, there has been a surge in the study of applying biotechnologies to geotechnical engineering by using microbial processes to change the physical and mechanical behaviour of soils and rocks. Methods based on this approach have been named biogeotechnologies. An overview of the research and development activities in this area in the past years is presented in this paper. The microbial effects that can be utilised in geotechnical engineering involve biocement, microbial desaturation, biofilm and so on. The applications of biogeotechnologies involve soil strengthening, seepage control, mitigation of soil liquefaction, soil erosion control, remediation of contaminated ground and so on. Problems and challenges related to methods for field implementation, monitoring and investigation techniques and environmental impacts are also discussed in this paper.

\section{Notation}

$D_{50} \quad$ mean size of soil particles

$k \quad$ permeability coefficient

$S_{\mathrm{r}} \quad$ degree of saturation

\section{Introduction}

Geotechnical engineering deals with the engineering behaviour of soils and rocks. There are a large number of microorganisms in soil and rock masses. In soils near ground surfaces, there are $10^{9}-10^{12}$ microorganisms in each kilogram of soil, and the microbial population decreases typically to the range $10^{6}-10^{11}$ at the $2-30 \mathrm{~m}$ depth range in geotechnical systems (DeJong et al., 2013; Mitchell and Santamarina, 2005). Microorganisms play an important role in the formation and evolution of soils and rocks under some conditions. The activities of microorganisms can influence the compositions, mineral types, fabric, strength, stiffness and permeability of soils (Dashko and Shidlovskaya, 2016; Mitchell and Santamarina, 2005). These activities can influence engineering practices both positively and negatively. It was reported that some engineering accidents including ground heaves and slope failures could be related to the activities of microorganisms (Mitchell and Santamarina, 2005). However, microorganisms and their activities are far more sophisticated than the physical, mechanical and chemical principles that form the fundamentals of geotechnical knowledge. Influencing factors such as temperature, $\mathrm{pH}$, redox condition and nutrient availability affect microbial activities in a complicated way, which gives rise to difficulties in understanding these activities and their influences on the geotechnical properties of soils and rocks. The role of microorganisms in the geotechnical field has been overlooked for decades.

In recent years, there has been an increasing interest in the study of bio-geotechnical interdisciplinary topics. The studies in this field can enrich the theories and methodologies of geotechnical engineering. More importantly, some activities of microorganisms can be harnessed to solve problems in geotechnical engineering. This technology is named biogeotechnology. In this paper, studies with respect to biogeotechnologies are introduced, classified and analysed. Many microbial processes can change the engineering properties of soils and rocks and can potentially be adopted in geotechnical engineering. Most of the research papers in this field have focused on the biocementation method that relies on the microbial ureolysis process. This is because of the advantages of this method over the others. These include relatively fast reaction rates and the amount of improvements in the mechanical properties of soil which could meet the demands of many engineering problems. Several other microbial methods, such as microbial desaturation and biofilm formation, can also be used to tackle geotechnical problems. However, these methods did not receive much attention compared with the biocementation method. As for the potential geotechnical applications, biogeotechnologies can be used for soil strengthening, seepage control, mitigation of soil liquefaction, soil erosion control, remediation of contaminated ground and so on. These microbial methods and their potential applications are reviewed and evaluated in this paper. In addition, problems and challenges related to the field implementation methods, monitoring and investigation techniques and environmental impacts are also discussed in the paper.

\section{Microbial effects}

\section{Biocement}

Some microbial processes can lead to the production of crystallised or non-crystallised inorganic compounds. These processes are named microbial mineralisation. When these microbial processes occur in soil, the produced inorganic compounds can fill soil pores or bind soil particles and therefore introduce true cohesion to the soil. This microbial effect on soil is similar to the effect of Portland cement. 
Therefore, the method of using the microbial process of cementing soil is named biocementation. Biocementation can be achieved through several microbial processes, including ureolysis (Al Qabany and Soga, 2013; Chu et al., 2012; DeJong et al., 2010; van Paassen et al., 2010a), denitrification (Fan, 2013; van Paassen et al., 2010b), sulfate-reducing processes (Warthmann, 2000) and iron-reducing processes (Chu and Ivanov, 2014; Weaver et al., 2011). The effective products that exert the biocementation effect in these processes are usually insoluble inorganic matter, including calcium carbonate and ferric hydroxide. If the produced inorganic matter is in crystallised form, very strong cementation effects can be produced that enhance the shear strength of soil. The biocementation process that produces calcite, the stable form of calcium carbonate, is called microbially induced carbonate precipitation (MICP). Calcium carbonate can be effectively produced through a microbial hydrolysis process. Ureolysis-based biocementation has been adopted in most of the related studies.

The reaction of ureolysis-based biocementation consists of two steps. In the first step, urea is hydrolysed into carbonate and ammonium ions, mediated by ureolytic bacteria

I. $\mathrm{NH}_{2}-\mathrm{CO}-\mathrm{NH}_{2}+2 \mathrm{H}_{2} \mathrm{O} \stackrel{\text { ureolytic bacteria }}{\longrightarrow} 2 \mathrm{NH}_{4}{ }^{+}+\mathrm{CO}_{3}{ }^{2-}$

In the second step, with the presence of aqueous calcium in the system, calcium carbonate can be precipitated

II. $\mathrm{Ca}^{2+}+\mathrm{CO}_{3}{ }^{2-} \rightarrow \mathrm{CaCO}_{3} \downarrow$

In the soil treatment procedure, bacteria and cementation solution (containing urea and calcium salt) are applied to the soil separately or together. At the microscale, bacteria tend to adhere to the surfaces of soils. The adherence of bacteria to soils is related to several factors, including the morphology, the surface texture and the mineralogy of soil particles; the hydrophobicity of cell surfaces; and the components and properties of pore water (Harkes et al., 2010). The microenvironment also plays an important role in the formation of the cementation effect (DeJong et al., 2010; Dhami et al., 2013; Rong et al., 2013). Urea can be hydrolysed by ureolytic bacteria, and the metabolic products, carbonate and ammonium, are generated around the bacterial cells. The cell surfaces of bacteria usually have negative charges, which attract cations such as calcium. Therefore, calcium carbonate precipitate tends to form and grow around bacterial cells. The growth of the precipitate will gradually fill soil pores and bridge soil particles. A scanning electron microscopy (SEM) image showing calcite crystals growing in sand pores is presented in Figure 1. At the macroscale, the precipitation and crystallisation of calcium carbonate lead to changes in soil properties in two aspects: increases in the shear strength and stiffness of soils, which are the so-called biocementation effects, and a decrease in the soil permeability, which is the so-called bioclogging effect. These two effects are

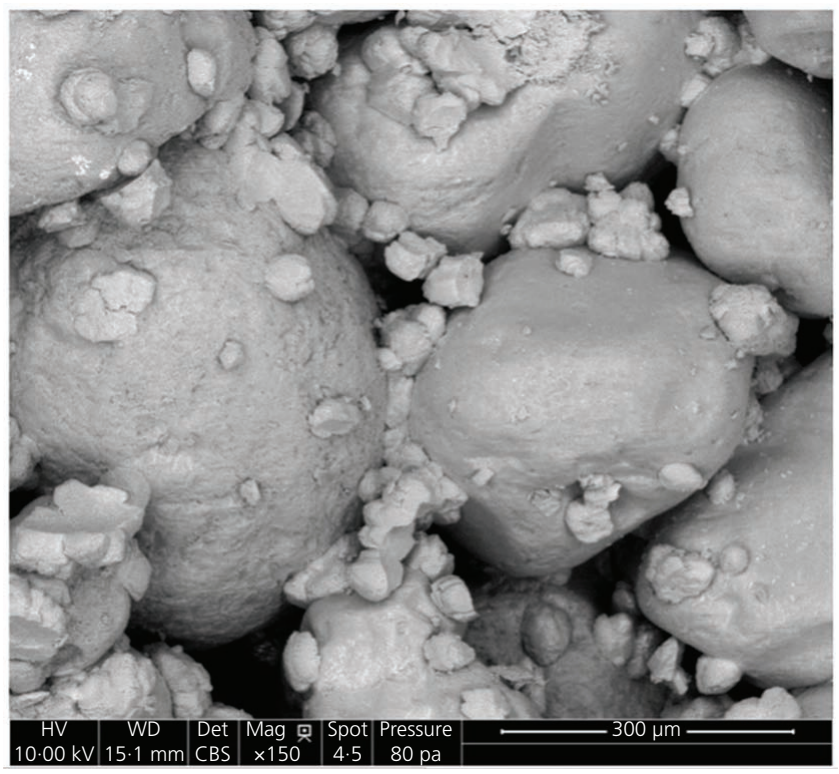

Figure 1. SEM image of biocemented sand

illustrated in Figure 2. In engineering practice, biocement treatment techniques, procedures and parameters can be tailored to produce more biocementation effect or bioclogging effect depending on the requirement. In related studies, the most widely used bacterial species is Sporosarcina pasteurii, thanks to its high ureolytic activity, tolerance to high alkalinity and salinity and spore-forming nature, which enable the bacteria to resist negative environments. Other species of ureolytic bacteria can be selected, such as Sporosarcina aquimarina and Bacillus megaterium, because of their adaptability to some special environments (Jiang et al., 2016). Using indigenous (native) ureolytic bacteria in soil for biocementation is an alternative way to externally introducing bacteria into soils (Gomez et al., 2017; Zhao, 2014). Recent studies
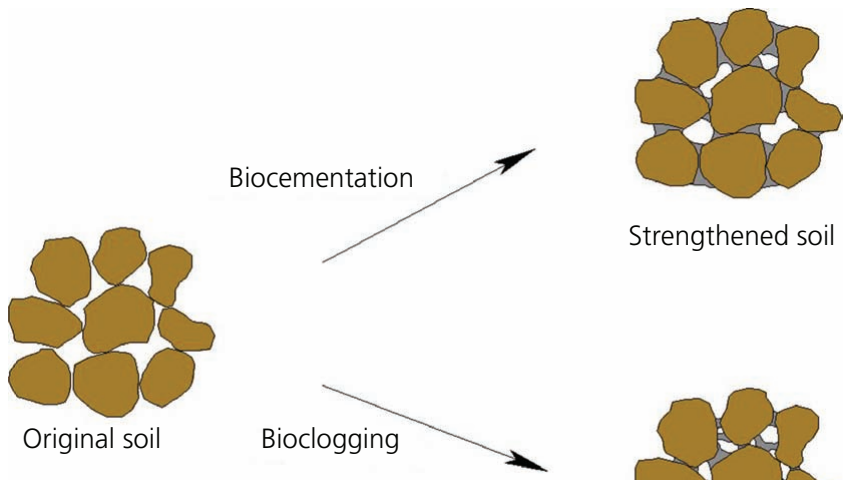

Strengthened soil

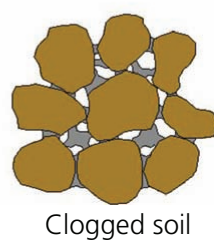

Figure 2. Schematic diagram of biocementation and bioclogging effects 
also showed that purified urease enzyme could also catalyse the ureolytic process and could induce biocementation and bioclogging effects in soils which were similar to those using live bacterial cells (Hamdan and Kavazanjian, 2016; Neupane et al., 2015a, 2015b). The mechanisms of using urease for the treatment and their pros and cons compared with live cells require further investigations. The soil improvement techniques based on these two effects will be introduced in the section headed 'Geotechnical applications'.

\section{Microbial desaturation}

Saturated sandy ground is usually susceptible to earthquake liquefaction. Desaturation of soils - that is, reduction of the saturation degree by adding or generating gas bubbles in soils can be a solution to reducing liquefaction susceptibility. This potential approach to solving the liquefaction problem has been gaining some research efforts (He et al., 2013; Rebata-Landa and Santamarina, 2012). In addition, desaturation of soils can be adopted as a technical measure to prevent the migration of contaminants in soil ground (He, 2013).

Many types of gases can be produced by microbial processes, including oxygen $\left(\mathrm{O}_{2}\right)$, hydrogen $\left(\mathrm{H}_{2}\right)$, carbon dioxide $\left(\mathrm{CO}_{2}\right)$ and nitrogen $\left(\mathrm{N}_{2}\right)$. Nitrogen gas can be produced from the microbial denitrification process in natural conditions. Nitrogen gas has stable chemical properties, and its solubility in water is very low $\left(0.017 \mathrm{~g} / 1\right.$ at $25^{\circ} \mathrm{C}$ and atmospheric pressure). Therefore, if the natural microbial denitrification process in soil is adopted to produce nitrogen gas and reduce the saturation degree of soil, the desaturation state of soil can be maintained for a relatively long time (He, 2013; Rebata-Landa and Santamarina, 2012). In addition, in subsoil under anaerobic or anoxic conditions, denitrification is the dominant process, as it has a higher negative Gibbs free energy change compared with other anaerobic processes (DeJong et al., 2010). Microbial denitrification and its characteristics are briefly introduced here. When denitrifying bacteria and substrate (including nitrate, electron donors and mineral nutrients) are present in soil pores, nitrate undergoes stepwise reduction reactions and the final product is nitrogen gas

III. $\mathrm{NO}_{3}^{-} \rightarrow \mathrm{NO}_{2}^{-} \rightarrow \mathrm{NO} \rightarrow \mathrm{N}_{2} \mathrm{O} \rightarrow \mathrm{N}_{2}$

Several organic matters can be used as electron donors in the microbial denitrification process, such as ethanol, acetate and glucose. The overall reaction equation with ethanol as the electron donor is

$$
\text { IV. } \begin{aligned}
5 \mathrm{C}_{2} \mathrm{H}_{5} \mathrm{OH}+12 \mathrm{KNO}_{3} \rightarrow & 6 \mathrm{~N}_{2} \uparrow+10 \mathrm{KHCO}_{3} \\
& +9 \mathrm{H}_{2} \mathrm{O}+2 \mathrm{KOH}
\end{aligned}
$$

It should be pointed out that whether nitrate can be completely reduced to nitrogen gas is dependent on several factors: concentrations of nitrate and nitrite (Blaszczyk et al., 1985; Glass and Silverstein, 1998; van Paassen et al., 2010b), pH values
(Saleh-Lakha et al., 2009; Simek et al., 2002), medium compositions (Blaszczyk, 1993) and temperature (Stanford et al., 1975). Precaution should be made regarding the nitrate, nitrite and some electron donors in the reaction process. When nitrate concentration is relatively high $(120 \mathrm{mM}$ or higher), nitrite will be accumulated in the reaction system and the high concentration of nitrite will impede further reduction reactions (van Paassen et al., 2010b). Nitrite and some electron donors are toxic or hazardous and should be strictly controlled to avoid environmental contamination. As for the bacterial species, most related studies adopted the enrichment culture technique to cultivate denitrifying bacteria or stimulate in situ denitrifying activities so that aseptic operations in the pure culture could be avoided (He et al., 2013; O'Donnell et al., 2017a, 2017b; van Paassen et al., 2010b).

\section{Biofilm}

Many microorganisms can excrete extracellular polymeric substances (EPSs). These slime-type polymers can attach to the surface of solid materials and form so-called biofilm. When biofilm is formed on the surfaces of soil particles, the permeability of soil can be significantly reduced. Biofilm and its clogging effect on porous media are ubiquitous in natural and artificial environments, and relevant research studies are popular in environmental sciences (Baveye et al., 1998; Thullner, 2010). The water content of biofilm is about $99 \%$. Biofilm-induced permeability reduction of soil mainly results from the pore-filling process, and another reason is the increase in the viscosity of pore fluid (Baveye et al., 1998). In some cases, the presence of biofilm is considered as an adverse factor, such as the clogging effects on the filter systems in water treatment processes (Bouwer, 2002; DeJong et al., 2013). However, in other cases, biofilm can potentially be used as an engineering measure to prevent or remediate water leakage in earth dams, dikes and reservoirs. The formation and degradation of EPSs are affected by many factors, as summarised by Baveye et al. (1998). These factors include type of porous materials, water content, temperature, redox condition, presence and type of nutrients, supply of nitrogen source and physiology of microorganisms. In laboratory experiments, many results have revealed that the permeability of porous media can be reduced by two to four orders of magnitude with the formation of biofilm (Ivanov and Chu, 2008; Proto et al., 2016; Thullner, 2010). It should be noticed that EPSs in soil can be degraded by other types of microorganisms, leading to the failure of leakage-control treatments (Farah et al., 2016; Ivanov and Chu, 2008). In related studies, biofilm-producing bacteria can be obtained by cultivating native bacteria in soils (Farah et al., 2016) or using slime-forming species such as Leuconostoc mesenteroides, Enterobacter aerogenes and Pseudomonas fluorescens (Abbasi et al., 2018; Proto et al., 2016).

\section{Geotechnical applications}

\section{Soil strengthening}

In the studies of biogeotechnologies, soil strengthening using the biocementation method receives most of the research efforts. Biocement is particularly suitable for the treatment of sandy soil, 
due to the high permeability of sand and easy transportation of bacteria and solutes in sand. Unconfined compression tests were adopted by many researchers to evaluate the strengths of biocemented sands. Some results of the unconfined compression tests on sands are summarised and presented in Figure 3. Although there are scatters in the data, the overall trend is that the higher the calcite content, the higher the shear strength. When the calcite content ranges from 5 to $25 \%$, the unconfined compression strength is roughly in the range of several hundred kilopascals to several megapascals. This range of strength for biocemented sands can satisfy most geotechnical applications. The scatter in the data possibly resulted from different types of sands, different treatment methods and different spatial distribution patterns of calcite in soil pores. With the same amount of cementing agents, soil treated by biocement has similar or slightly higher strength compared with soil treated by Portland cement (Li, 2015). Other types of geotechnical tests have also been used to assess the mechanical behaviour and liquefaction responses of biocemented sand, including direct shear tests, quasi-static and cyclic triaxial tests and shaking table tests. In direct shear and triaxial tests, biocemented sands showed an increase in both internal friction angles and cohesions, indicating the clear improvement in shear strength (Chou et al., 2011; Cui et al., 2017). In triaxial drained conditions, biocemented sands manifested higher stiffness and dilatancy compared with untreated sand (DeJong et al., 2006; Lin et al., 2016; Montoya and DeJong, 2015; O'Donnell and Kavazanjian, 2015). In the process of shearing, cementation effects gradually degrade. However, due to the effect of pore filling and the change in the particle shape, the residual strength of biocemented sand is still higher than that of untreated sand,

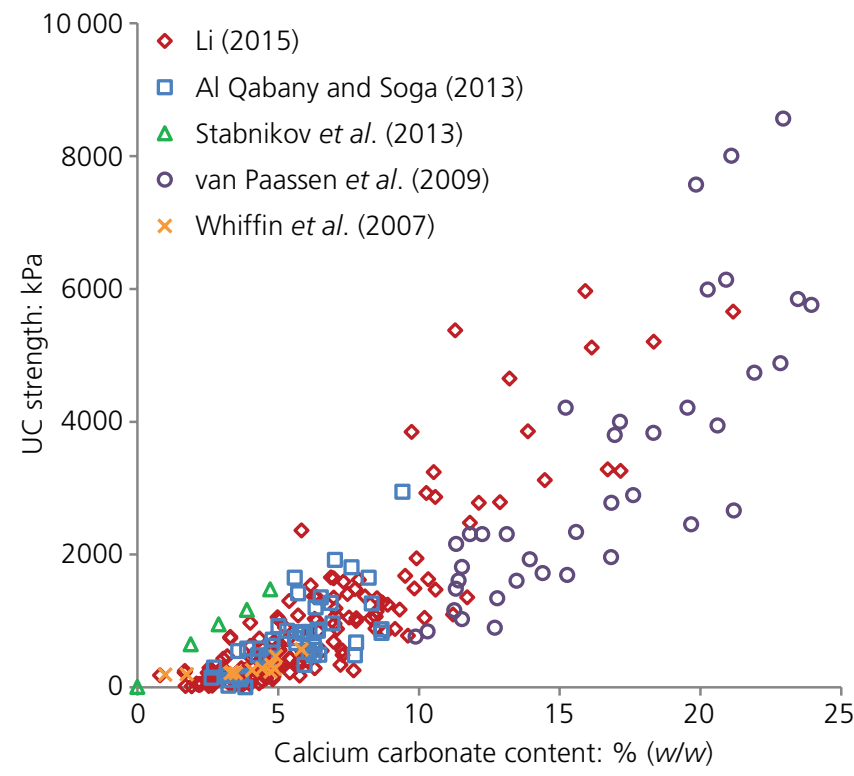

Figure 3. Relationship between unconfined compression (UC) strength and calcium carbonate content for sand (Al Qabany and Soga, 2013; Li, 2015; Stabnikov et al., 2013; van Paassen et al., 2009; Whiffin et al., 2007) even when the cementation effect is completely destroyed (DeJong et al., 2010). It was reported that the strength of biocemented sands is also influenced by factors including the density states of original soils, particle sizes and confining pressures (Chou et al., 2011; Cui et al., 2017; Feng and Montoya, 2016; Zamani and Montoya, 2018). The mechanical behaviour and liquefaction responses of biocemented soil under dynamic load are also of great interest (Cheng et al., 2013; Han et al., 2016; Montaya et al., 2013; Sasaki and Kuwano, 2016). In cyclic triaxial tests, biocemented sand also has much higher strength than untreated sand and the liquefaction susceptibility is basically eliminated (Feng and Montoya, 2017; Han et al., 2016; Sasaki and Kuwano, 2016). In shaking table tests, biocemented sand manifests favourable responses compared with untreated sand by showing lower excess pore pressure and smaller soil deformation. It was reported by Montaya et al. (2013) that when the calcite content was relatively high, soil ground could amplify the acceleration in an earthquake event (Montaya et al., 2013). However, in another study, it was reported that whether acceleration increased or decreased in biocemented soil ground is dependent on the magnitude and frequency of the acceleration (Cheng et al., 2013).

The treatment methods of using biocement are different from conventional soil improvement methods. For the treatment of sand using biocement, the usual way is to have bacteria and cementation solutions permeate sand. The reaction takes place, and calcium carbonate forms along the flow path. Therefore, the treatment outcome is affected by many factors, including the amount and activity of bacteria, the composition of the cementation solution or pore fluid, flow rate and direction and the characteristics of porous media. The spatial distribution of calcium carbonate and the related mechanical behaviour of soil are strongly influenced by the distribution of bacteria and their activities (Harkes et al., 2010; Martinez et al., 2013). In the study of Harkes et al. (2010), water with various salinities was used to adjust the distribution of bacteria in soils in order to obtain relatively uniformly distributed calcite throughout the soil, as the mobility of bacteria in soil is strongly affected by the salinity of pore water. With the same amount of calcium carbonate produced, cementation solutions with lower concentrations lead to more uniformly distributed calcite and thus have better treatment effects in terms of strength improvement (Al Qabany and Soga, 2013; Al Qabany et al., 2012). Reducing the molar ratio of urea to calcium leads to less production of ammonia, which is a byproduct of the ureolysis process (Martinez et al., 2013). Flow rates, directions and patterns can be regulated to optimise the treatment effects. The uniformity of calcite precipitation can be enhanced by discontinuous flow with the cementation solution retained in soil for some time or by changing flow directions in the treatment process (Martinez et al., 2013). Keeping soil in the unsaturated state during the treatment process also facilitates a better treatment effect in terms of strength improvement, because calcium carbonate tends to form at the particle contacts (Cheng et al., 2012; Simatupang and Okamura, 2017). Treatment effects 
and quality are also influenced by many other factors, including oxygen availability, temperature, rainwater flushing, oil contamination and freeze-thaw cycling (Cheng et al., 2017; Chu et al., 2014; Jiang et al., 2016). Attempts have been made on the development of different biocement application techniques so as to improve treatment quality (Cheng and Shahin, 2016; Chu et al., 2015; Mahawish et al., 2016). Biocement has been tested for the treatment of clay or silt soils (Ivanov et al., 2015; Li, 2015; Li et al., 2016; Soon et al., 2014). The voids in clay and silt soils are too small to allow the transport of bacteria inside. Thus, the bulk treatment of clay and silt soils is difficult. Some studies suggest that this difficulty can be overcome by fully mixing soil and bacteria together (DeJong et al., 2013; Li, 2015). However, soil mixing requires special equipment that is relatively expensive to be used at large scale. Other options for the treatment of clay or silt may involve the use of the enzyme urease or the stimulation of indigenous bacteria (Gomez et al., 2017; Hamdan and Kavazanjian, 2016; Jiang et al., 2016; Neupane et al., 2013, 2015a; Zhao et al., 2014). On the other hand, there are also data showing that the biocementation effect achieved through mixing soil with bacterial enzyme is significantly lower than that through injection (Almajed et al., 2018).

Biocement is suitable for the improvement of sandy soil ground with relatively high permeability. The treatment process causes much less disturbance to the ground, compared with conventional cement-based ground improvement methods. Therefore, biocementation methods can be used for the treatment of grounds beneath existing buildings and structures and grounds with buried structures and pipelines. One of the field experiments on the stabilisation of the boreholes in gravel ground was reported by van Paassen (2011). The treatment volume was $1000 \mathrm{~m}^{3}$, and the treatment depth was from 3 to $20 \mathrm{~m}$. Bacteria and cementation solutions were injected into the wells on one side of the ground and extracted from the wells on the other side. The ground monitoring and investigation showed that the treatment was successful.

\section{Seepage control in soils and rocks}

Biogeotechnologies can be used for seepage control in soils and rocks. The microbial processes mentioned in the section headed 'Microbial effects' including biocement, microbial desaturation and biofilm can all serve as measures to reduce the permeability and control water seepage. For the biocementation method, the permeability of biocemented sand in relation to the calcite content summarised from previous studies is presented in Figure 4 (Al Qabany and Soga, 2013; Chu et al., 2013; Li, 2015; Whiffin et al., 2007). The concentrations of treatment solution (urea) used in these studies were in the range $0.5-1.5 \mathrm{M}$. The mean sizes $D_{50}$ of the sand were in the range $0 \cdot 165-0 \cdot 420 \mathrm{~mm}$. It can be seen that the permeability shows a sharp decrease when the calcite content increases from 0 to around $2 \%$. Beyond this range, the variation in permeability in relation to calcite content was moderate. Permeability could be reduced to a minimum value of around $1 \times$ $10^{-6} \mathrm{~m} / \mathrm{s}$ at $15 \%$ calcite content, or about two order-of-magnitude

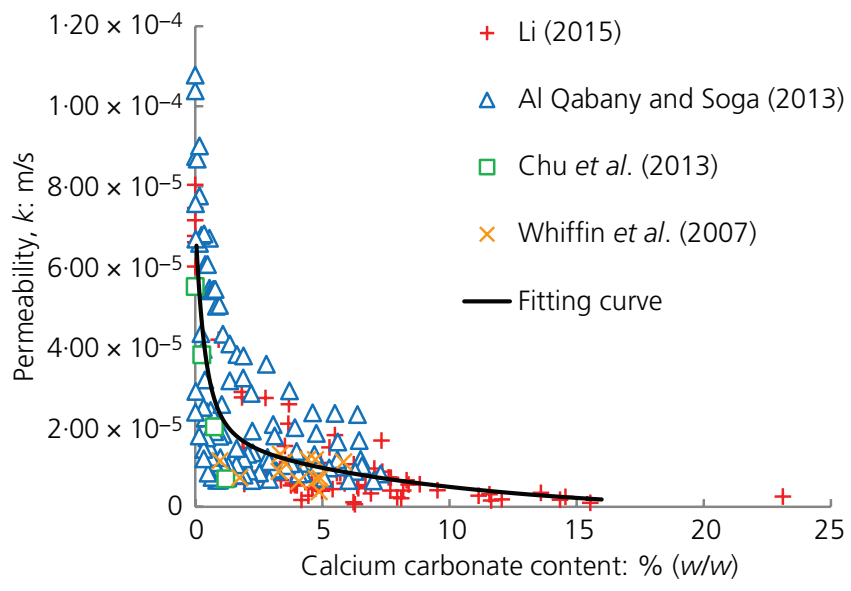

Figure 4. Relationship between the permeability and the calcium carbonate content of uniform MICP-treated sand in previous studies (the urea concentrations in the treatment solutions range from 0.5 to $1.5 \mathrm{M}$; the mean sizes $D_{50}$ of the sand range from 0.165 to $0.420 \mathrm{~mm}$ ) (Al Qabany and Soga, 2013; Chu et al., 2013; Li, 2015; Whiffin et al., 2007)

reduction compared with untreated sand. Biofilm consisting primarily of EPS can significantly reduce the permeability of porous materials and can be used for seepage control in soils. Experimental data indicate that the permeability of sand reduces from $10^{-4}$ to $10^{-6} \mathrm{~m} / \mathrm{s}$ with the formation of biofilm inside the sand pores (Ivanov and Chu, 2008). In a field experiment, the leakage volume in an earth dike reduced by around one order of magnitude through the biofilm method (Blauw et al., 2009). The permeability of soil can be reduced by reducing the saturation degree through induction of gas bubbles in soil pores. It is shown by Chu et al. (2009a) that by reducing the saturation degree of sand from 100 to $82 \%$ permeability can be reduced by a factor of 3. The biocement-based grouting method can be applied to control water seepage or contaminant migration through rock fractures (Cuthbert et al., 2013; Lambert et al., 2010; Phillips et al., 2013). An experimental study showed that by repairing rock cracks by using biocement, permeability could be reduced by two to four orders of magnitude; after the repair, the strength of the rock was even higher than the intact rock without any cracks inside (Phillips et al., 2013).

Bioclogging effects have many potential applications, including seepage control in earth dams and dikes, prevention of leakage in reservoirs and seepage control during excavations ( $\mathrm{Chu}$ et al., 2013; Cuthbert et al., 2013; James et al., 2000; Lambert et al., 2010; Phillips et al., 2013; Seki et al., 1998). In the construction or remediation of reservoirs and water channels, microbial treatment materials can be applied directly to the surface soil for the formation of an impermeable biocement layer (Chu et al., 2012, 2013). For the remediation of earth dams and dikes, treatments can be applied to the leakage locations; the formation of a biocement curtain is also suitable to cut off the flow path in dams and dikes (Chu et al., 2014). For the repair of cracks in 
rocks and concretes, the grouting method is more suitable, because of the fluid nature of biocement materials and the related large treatment extent. Field experiments on bioclogging techniques have been reported (Blauw et al., 2009; Cuthbert et al., 2013; van Meurs et al., 2006). In one of the experiments in Austria, nutrients were injected into the leakage location in a river dike to stimulate the growth of biofilm in situ (Blauw et al., 2009). The leakage rate was reduced by around one order of magnitude after two passes of nutrient injections. In another experiment, biocement was applied to fractured rocks to solve the seepage problem in the rock (Cuthbert et al., 2013). The results showed that the permeability was reduced within the treatment range.

\section{Mitigation of soil liquefaction through microbial desaturation}

Studies have revealed that the liquefaction resistance of saturated sand can be enhanced by reducing its saturation degree, or desaturation (He, 2013; Okamura and Soga, 2006; Tsukamoto et al., 2002; Yang et al., 2004). Liquefaction countermeasures based on this soil behaviour have been developed. The advantage of these liquefaction countermeasures can potentially be more cost-effective and easier to be implemented compared with conventional soil improvement methods and the ureolysis-based biocementation method. Laboratory investigations showed that, by reducing the saturation degree by merely several percentages, the undrained shear strength of originally saturated loose sand can be greatly enhanced under both quasi-static and cyclic loading conditions (He and $\mathrm{Chu}, 2014$; He et al., 2014; Okamura and Soga, 2006; Tsukamoto et al., 2002; Yang et al., 2004). In triaxial consolidated undrained tests on the loose sand samples, decreasing the saturation degree leads to a change in the stress-strain behaviour from a strain-softening manner to a strainhardening manner, indicating the improvement of liquefaction resistance (He and Chu, 2014; He et al., 2014). It was also shown in shaking table tests that desaturated sand has much higher liquefaction resistance than saturated sand (He et al., 2013). Results of the shaking table tests on two sand samples, one saturated sample and one desaturated sample with $90 \%$ saturation degree, are comparatively presented in Figure 5. In the desaturated sample, the excess pore water generation, the volume change of soil and the subsidence of structure on the soil are all greatly reduced compared with those in the saturated sample.

In order to reduce the degree of saturation of sand and improve its liquefaction resistance, several techniques have been proposed and tested, including the air injection method (Okamura et al., 2011), the water electrolysis method (Yegian et al., 2007), the chemical method (Eseller-Bayat et al., 2013) and the microbial method (He, 2013). The advantages of using the denitrificationbased microbial method are the following: gas bubbles are generated inside soil pores so that they can be more uniformly distributed; the microbial process is relatively slow, so it can be easily controlled; and the nitrogen gas produced in the

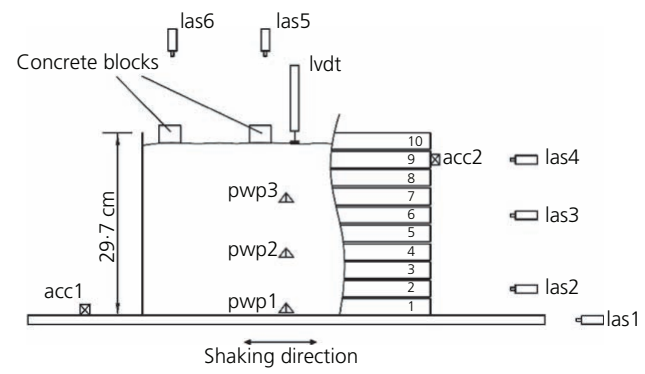

(a)

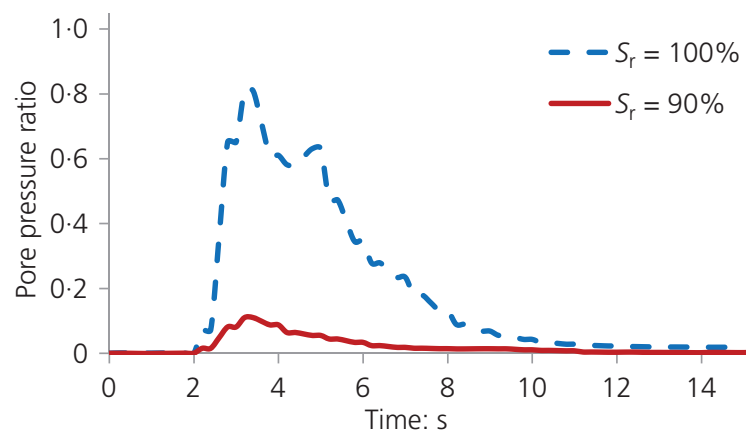

(b)

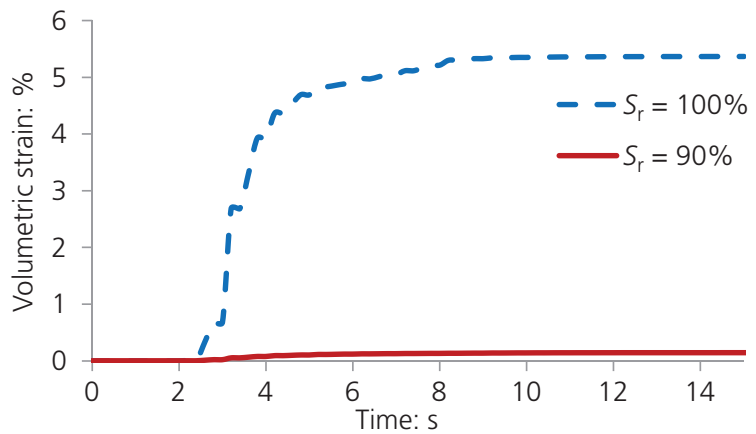

(c)

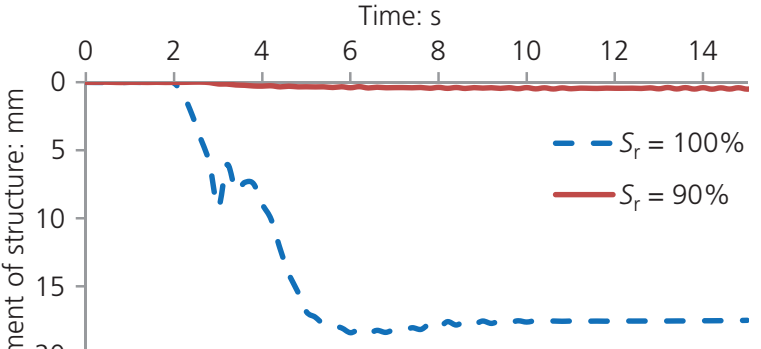

(d)

Figure 5. Results of shaking table tests on two specimens with $S_{r}$ of 100 and 90\%: (a) shaking table test model; (b) pore pressure ratio; (c) volumetric strain; (d) settlement of structure 
denitrification process is physically and chemically stable so that the gas bubbles can stay in soil grounds for a relatively long time.

\section{Soil erosion control}

Soils and earth structures are susceptible to erosion by winds or hydraulic forces. Biocement can be used to control the soil erosion or suppress dust pollution (Bang et al., 2011; Hamdan and Kavazanjian, 2016; Jiang et al., 2014; Maryam, 2014). Earth dikes can be easily destroyed by overtopping erosion during flood. If earth dikes are coated by a layer of biocement crust that is resistance to overtopping, erosion can be enhanced. A model test is shown in Figure 6 (Maryam, 2014). The earth dike received biocement treatment on the surface six times. The distribution of calcite from the surface down is shown in Figure 6(b). Calcite mainly existed in the $3 \mathrm{~cm}$ deep range. The treated dike model underwent overtopping erosion in a hydraulic flume for $30 \mathrm{~d}$, and it remained stable. Dust from construction sites can cause serious air pollution. Thanks to the fluid nature of the treatment materials used, biocement and biofilm can be easily applied onto soil surfaces to control surface erosion (DeJong et al., 2013; Ham et al., 2018). Piping erosion is a form of seepageinduced erosion where smaller particles in soil are taken away through larger soil pores and the remaining soil collapses. It was

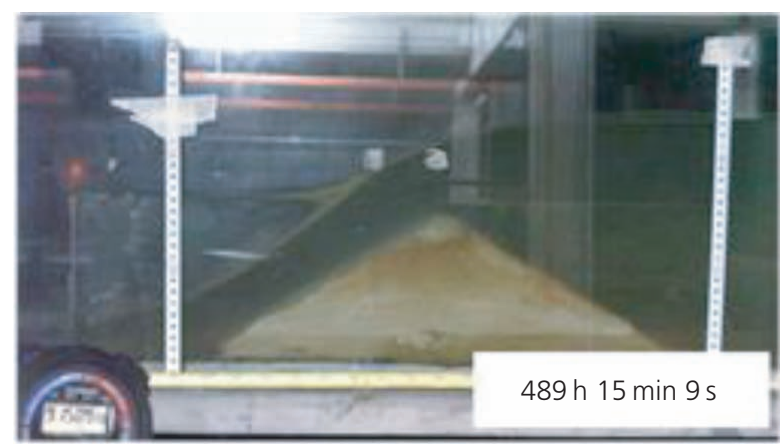

(a)

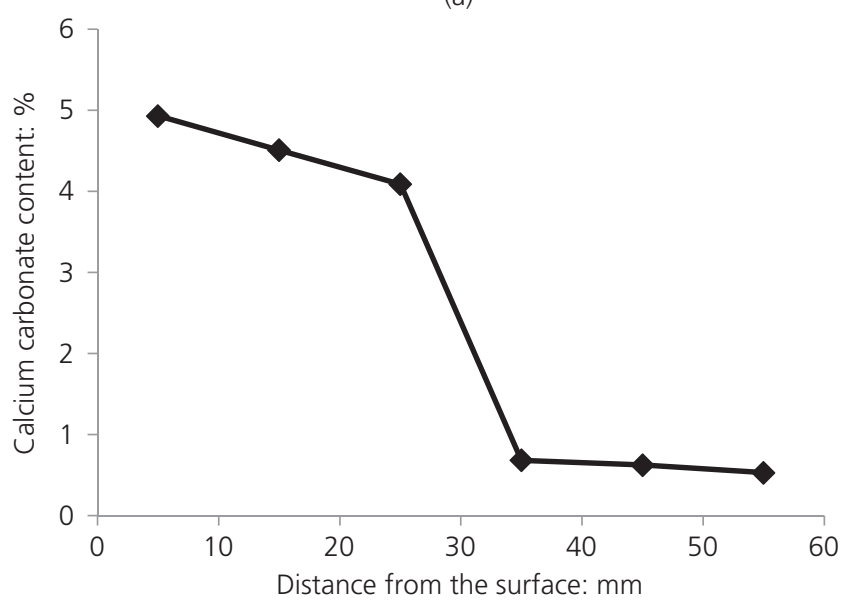

(b)

Figure 6. Biocemented dike model under water erosion: (a) model test; (b) calcium carbonate content along the depth shown that the susceptibility to piping erosion of soils could be greatly reduced by biocement treatment (Jiang and Soga, 2017; Jiang et al., 2014, 2017).

\section{Remediation of contaminated ground}

Another potential application area of biogeotechnologies is the remediation of contaminated ground. As mentioned earlier in the paper, microbial processes can produce bioclogging effects, which can be adopted to control the migration of contaminants into the ground (Babu and Mastan, 2008; Mani and Chitranjan, 2014; Tang et al., 2018). Furthermore, biocement has been studied for the stabilisation of heavy metals in contaminated soil grounds. Through the treatment of biocement, carbonate salts of heavy metals can be precipitated and stabilised. In laboratory studies, metals that can be fully or partly stabilised by biocement involve nickel, copper, lead, cobalt, zinc and cadmium (Li et al., 2013a, 2013b; Lu et al., 2012; Qian et al., 2011; Wang et al., 2007). The treatment efficiencies ranged from 50 to $99 \%$ in these studies. Factors affecting the treatment effects involve concentrations of metals, pH value and temperature (Xu et al., 2012, 2013). Relatively high concentrations of metals can inhibit the activity of bacteria and thus slow down the reaction process, but the reaction process can still proceed at a slow but acceptable rate. In weak acidic environments $(5<\mathrm{pH}<7)$, the activity of bacteria is low but usable; when $\mathrm{pH}<5$, the activity is too low and contaminated soils can be neutralised prior to biocement treatment. The activity of bacteria increases with temperature, and the activity is acceptable at a temperature as low as $15^{\circ} \mathrm{C}$. In a field experiment, urea and molasses were injected into a soil ground polluted by strontium-90 in order to stabilise the heavy metal (Fujita et al., 2010). The injection of molasses was done to stimulate the activity of native bacteria. The treatment solution was circulated through injection and extraction wells. Bacterial activity and heavy metal precipitation were detected in the ground. In another field experiment, biocement solution was sprayed onto the surface of a contaminated ground to stabilise the heavy metal in the top $20 \mathrm{~cm}$ of soil (Xu et al., 2013). It was found that exchangeable-form heavy metals were reduced by $61 \%$. In addition to bioclogging and biostabilisation, bacteria and other microorganisms such as fungi and algae have versatile applications in geoenvironmental engineering including biodegradation of contaminants and biodesorption of attached materials in soils (Babu and Mastan, 2008; Mani and Chitranjan, 2014; Tang et al., 2018).

\section{Other applications}

Biogeotechnologies also have many other potential applications, as proposed in previous studies. These potential applications involve carbon dioxide sequestration in shallow soil (Manning, 2008) and deep ground (DeJong et al., 2013), enhancement of soil oil exploitation rate (DeJong et al., 2013) and so on. In addition, some waste and recycled materials can be used as raw materials for biocement. For example, the calcium source and nutrients for the cultivation of bacteria can be obtained from industrial, agricultural and domestic waste materials (Choi et al., 2016; Chu et al., 2009b, 2014; DeJong et al., 2013). 


\section{Problems and challenges}

\section{Field implementation methods}

Biocement and other materials used in the biogeotechnologies are usually in a liquid form that contains bacterial suspensions and treatment solutions. This feature can bring many advantages. For shallow or surface treatment of soil, biocement materials can simply be sprayed or poured on the surface of soil. For deep or bulk soil treatment, treatment materials can be injected into the wells on one side of the treated ground and extracted from the wells on the other side, so that microbial reactions take place in the soil ground (van Paassen, 2011). This means that field implementation does not cause major ground disturbance and the construction cost can be reduced. Furthermore, the biotechnologies can be used for the treatment of soil grounds under existing buildings and structures. On the other hand, the fluid nature of treatment materials may also cause difficulties. The treatment effect throughout the ground is often non-uniform. The uniformity of the treatment effect is governed by many factors which are not easy to control during the treatment process, as mentioned in the section headed 'Soil strengthening'. Biocement treatment is also difficult to use for fine-grained soil, as discussed before. In natural ground conditions, soil particles with different sizes are often mixed. Unless the permeability of the soil is greater than $10^{-5} \mathrm{~m} / \mathrm{s}$, percolation or injection methods may not be effective and soil mixing may have to be used (DeJong et al., 2013; Li, 2015). Other options involve using purified enzymes a size smaller than that of live bacteria or cultivating and using native bacteria (Gomez et al., 2017; Hamdan and Kavazanjian, 2016; Jiang et al., 2016; Neupane et al., 2013, 2015a; Zhao et al., 2014).

At present, in most of the studies, the cultivation of bacteria requires high-purity chemical reagents and special laboratory equipment for aseptic operations, which can be hardly applied to large-scale practices. Therefore, efforts can be made in future studies on the development of economical and technically reliable methods for the cultivation of microorganisms. For example, by using a special medium and controlling some environment factors during the cultivation, ureolytic bacteria can be cultivated in a chemostat and an open condition, which greatly reduce the cost and improve the bacterial production rate (Cheng and CordRuwisch, 2013).

\section{Monitoring and investigations}

In any project using microbial methods for soil improvement, field monitoring should be carried out to ensure treatment quality. Geophysical methods are suitable for monitoring and investigations. Shear or compressive wave velocities obtained from geophysical investigations can be used to obtain shear and bulk moduli, which are reflections of cementation effects and degree of saturation of soils, respectively (Tsukamoto et al., 2002; van Paassen et al., 2010a). Electrical conductivity can also be measured by geophysical methods. Electrical conductivity is a good indication of the progresses of microbial ureolysis and denitrification processes due to the changes in the ionic concentrations during the reaction processes (van Paassen, 2011). Tracer methods can be used to detect the water flow in the microbial treatment processes and to evaluate the quality of bioclogging effects (Lambert et al., 2010). In addition to these new monitoring and investigation methods, conventional ground investigation and sampling methods in geotechnical and environmental engineering can also be adopted for the evaluation of the microbial treatment effects.

\section{Environmental impacts}

One major environmental concern is the production of hazardous and toxic matter, such as ammonia produced from the ureolytic process. The amount of ammonia can be reduced by adjusting the urea-calcium chloride ratio in the biocement solutions. The amount of ammonia gas can be eliminated through the use of low-pH solutions. Nevertheless, the potential environmental risks of ammonia should be evaluated and monitored in field implementation. If necessary, the ammonia produced should be collected and treated on-site. An alternative to avoid the production of ammonia is to use the denitrification-based biocementation method (O'Donnell et al., 2017a, 2017b; van Paassen et al., 2010b). However, the biocementation effect using the denitrification process is not as efficient as the ureolysis-based biocement at the moment. Furthermore, nitrite, an intermediate in the microbial denitrification process, is also toxic and can potentially cause pollution to soil grounds and underground water.

Another environmental concern is whether the microorganisms are non-pathogenic and non-hazardous to humans and the environment. This issue can be addressed by several solutions. First, microorganisms used in microbial methods can be obtained from microbial culture collection agents, such as the American Type Culture Collection in the USA and Deutsche Sammlung von Mikroorganismen und Zellkulturen in Germany. The safety levels and safe operation procedures of the microorganisms from these agents are clearly stated. Second, if the microorganisms are obtained from external environments, the isolated strains can be genetically identified, and, thus, the safety levels can be analysed. Third, for the microbial treatment of soil ground, microbial activity can be obtained by stimulating the growth of native bacteria, which causes less disturbance to soil environments compared with introducing bacteria externally (Gomez et al., 2017; Zhao, 2014).

\section{Summary and conclusions}

As an emerging research field, biogeotechnologies have made significant advances in the past decade. In this paper, some biogeotechnologies related to the use of microbes and various geotechnical applications are summarised. The microbial effects that can be utilised in geotechnical engineering involve biocement, microbial desaturation, biofilm and so on. The applications of biogeotechnologies involve soil strengthening, seepage control, mitigation of soil liquefaction, soil erosion control, remediation of contaminated ground and so on. 
Difficulties and problems in relation to the field implementation methods, monitoring and investigation techniques and environmental impacts are also discussed.

Microbial processes are far more complicated than physical and chemical processes in general. This gives many difficulties to the study and the adoption of biogeotechnologies. The microbial processes are affected by many factors, so the control and regulation of the microbial processes are difficult. Many experimental results found in laboratories are hard to explain. In related studies, the ureolysis-based biocementation method receives most of research attention, while the studies on other microbial processes and applications are still in the very early stages. Therefore, it can be said that there are still many problems to overcome before large-scale applications of biogeotechnologies can be considered. As an interdisciplinary topic, the research and development work demands collaboration between researchers from geotechnical engineering and biotechnologies.

\section{Acknowledgements}

This work was financially supported by the Ministry of Education, Singapore (number MOE2015-T2-2-142), Centre for Usable Space (Nanyang Technological University, Singapore), the National Natural Science Foundation of China (numbers 51608169, 41630638 and 51609093), the National Key Research and Development Program of China (number 2016YFC0800205), the 111 Project (Ministry of Education of China, number B13024) and the Jiangsu Provincial Natural Science Foundation of China (number BK20150814).

\section{REFERENCES}

Abbasi B, Ta HX, Muhunthan B et al. (2018) Modeling of permeability reduction in bioclogged porous sediments. Journal of Geotechnical and Geoenvironmental Engineering 144(4): 06018016, https://doi.org/ 10.1061/(ASCE)GT.1943-5606.0001869.

Al Qabany A and Soga K (2013) Effect of chemical treatment used in MICP on engineering properties of cemented soils. Géotechnique 63(4): 331-339, https://doi.org/10.1680/geot.SIP13.P.022.

Al Qabany A, Soga K and Santamarina JC (2012) Factors affecting efficiency of microbially induced calcite precipitation. Journal of Geotechnical and Geoenvironmental Engineering 138(8): 992-1001, https://doi.org/10.1061/(ASCE)GT.1943-5606.0000666.

Almajed A, Tirkolaei HK and Kavazanjian E (2018) Baseline investigation on enzyme-induced calcium carbonate precipitation. Journal of Geotechnical and Geoenvironmental Engineering 144(11): 04018081, https://doi.org/10.1061/(ASCE)GT.1943-5606.0001973.

Babu TEG and Mastan SA (2008) Role of bacteria in bioremediation of heavy metals. Journal of Pure and Applied Microbiology 2(2): 519-524.

Bang S, Min SH and Bang SS (2011) Application of microbiologically induced soil stabilization technique for dust suppression. International Journal of Geo-engineering 3(2): 27-37.

Baveye P, Vandevivere P, Hoyle BL, DeLeo PC and de Lozata DS (1998) Environmental impact and mechanisms of the biological clogging of saturated soils and aquifer materials. Critical Reviews in Environmental Science and Technology 28(2): 123-191, https://doi. org/10.1080/10643389891254197.

Blaszczyk M (1993) Effect of medium composition on the denitrification of nitrate by Paracoccus denitrificans. Applied and Environmental Microbiology 59(11): 3951-3953.
Blaszczyk M, Galka E, Sakowicz E and Mycielski R (1985) Denitrification of high concentrations of nitrites and nitrates in synthetic medium with different sources of organic carbon: III. methanol. Acta Microbiologica Polonica 34(2): 195-205.

Blauw M, Lambert JWM and Latil MN (2009) Biosealing: a method for in situ sealing of leakages. Proceedings of the International Symposium on Ground Improvement Technologies and Case Histories, Singapore, pp. $125-130$.

Bouwer H (2002) Artificial recharge of groundwater: hydrogeology and engineering. Journal of Hydrology 10(1): 121-142, https://doi.org/10. 1007/s10040-001-0182-4.

Cheng $L$ and Cord-Ruwisch R (2012) Selective enrichment and production of highly urease active bacteria by non-sterile (open) chemostat culture. Journal of Industrial Microbiology and Biotechnology 40(10): 1095-1104, https://doi.org/10.1007/s10295-013-1310-6.

Cheng L and Shahin MA (2016) Urease active bioslurry: a novel soil improvement approach based on microbially induced carbonate precipitation. Canadian Geotechnical Journal 53(9): 1376-1385, https://doi.org/10.1139/cgj-2015-0635.

Cheng L, Cord-Ruwisch R and Shahin MA (2012) Cementation of sand soil by microbially induced calcite precipitation at various degrees of saturation. Canadian Geotechnical Journal 50(1): 81-90, https://doi. org/10.1139/cgj-2012-0023.

Cheng XH, Ma Q, Yang Z, Zhang ZC and Li M (2013) Dynamic response of liquefiable sand foundation improved by bio-grouting, China. Chinese Journal of Geotechnical Engineering 35(8): 1486-1495.

Cheng L, Shahin MA and Mujah D (2017) Influence of key environmental conditions on microbially induced cementation for soil stabilization. Journal of Geotechnical and Geoenvironmental Engineering 143(1): 04016083, https://doi.org/10.1061/(ASCE)GT.1943-5606.0001586.

Choi SG, Chu J and Wu SF (2016) Biocementation for sand using an eggshell as calcium source. Journal of Geotechnical and Geoenvironmental Engineering 142(10): 06016010, https://doi.org/10. 1061/(ASCE)GT.1943-5606.0001534.

Chou CW, Seagren EA, Aydilek AH and Lai M (2011) Biocalcification of sand through ureolysis. Journal of Geotechnical and Geoenvironmental Engineering 137(12): 1179-1189, https://doi.org/10.1061/(ASCE)GT. 1943-5606.0000532.

Chu J and Ivanov V (2014) Iron- and calcium-based biogrouts for soil improvement. In Geo-Congress 2014 Technical Papers: GeoCharacterization and Modeling for Sustainability (Abu-Farsakh M, Yu X and Hoyos LR (eds)). American Society of Civil Engineers, Reston, VA, USA, Geotechncial Special Publication no. 234, pp. 1596-1601.

Chu J, Ivanov V, He J and Maryam N (2009a) Microbial geotechnical engineering for disaster mitigation and coastal management. Proceedings of WCCE-ECCE-TCCE Joint Conference: Earthquake \& Tsunami, Istanbul, Turkey, pp. 1-6.

Chu J, Ivanov V, Lee MF, Oh XM and He J (2009b) Soil and waste treatment using biocement. Proceedings of the International Symposium on Ground Improvement Technologies and Case Histories, Singapore, pp. 165-170.

Chu J, Stabnikov V and Ivanov V (2012) Microbially induced calcium carbonate precipitation on surface or in the bulk of soil. Geomicrobiology Journal 29(6): 544-549, https://doi.org/10.1080/ 01490451.2011 .592929$.

Chu J, Ivanov V, Stabnikov V and Li B (2013) Microbial method for construction of aquaculture pond in sand. Géotechnique 63(10): 871-875, https://doi.org/10.1680/geot.SIP13.P.007.

Chu J, Ivanov V, Naeimi M, Stabnikov V and Liu HL (2014) Optimization of calcium-based bioclogging and biocementation of sand. Acta Geotechnica 9(2): 277-285, https://doi.org/10.1007/s11440-013-0278-8.

Chu J, Ivanov V, He J, Maryam N and Wu SF (2015) Use of biogeotechnologies for soil improvement. In Ground Improvement Case Histories: Chemical, Electrokinetic, Thermal, and 
Bioengineering Methods (Indraratna B, Chu J and Rujikiatkamjorn C (eds)). Elsevier, Amsterdam, the Netherlands, pp. 571-590.

Cui MJ, Zheng JJ, Zhang RJ, Lai HJ and Zhang J (2017) Influence of cementation level on the strength behaviour of bio-cemented sand. Acta Geotechnica 12(5): 971-986, https://doi.org/10.1007/s11440-017-0574-9.

Cuthbert MO, Mcmillan LA, Handley-Sidhu S et al. (2013) A field and modeling study of fractured rock permeability reduction using microbially induced calcite precipitation. Environmental Science \& Technology 47(23): 13637-13643, https://doi.org/10.1021/es402601g.

Dashko R and Shidlovskaya (2016) Impact of microbial activity on soil properties. Canadian Geotechnical Journal 53(9): 1386-1397, https:// doi.org/10.1139/cgj-2015-0649.

DeJong JT, Fritages MB and Nusslein K (2006) Microbially induced cementation to control sand response to undrained shear. Journal of Geotechnical and Geoenvironmental Engineering 132(11): 1381-1392, https://doi.org/10.1061/(ASCE)1090-0241(2006)132:11 (1381).

DeJong JT, Mortensen MB, Martinez BC and Nelson DC (2010) Biomediated soil improvement. Ecological Engineering 36(2): 197-210, https://doi.org/10.1016/j.ecoleng.2008.12.029.

DeJong JT, Soga K, Kavazanjian E et al. (2013) Biogeochemical processes and geotechnical applications: progress, opportunities and challenges. Géotechnique 63(4): 287-301, https://doi.org/10.1680/geot.SIP13.P. 017.

Dhami NK, Reddy MS and Mukherjee A (2013) Biomineralization of calcium carbonates and their engineered applications: a review. Frontiers in Microbiology 4(314): 1-13, https://doi.org/10.3389/fmicb. 2013.00314.

Eseller-Bayat E, Yegian M, Alshawabkeh A and Gokyer S (2013) Liquefaction response of partially saturated sands: I: experimental results. Journal of Geotechnical and Geoenvironmental Engineering 139(6): 863-871, https://doi.org/10.1061/(ASCE)GT.1943-5606. 0000815 .

Fan SS (2013) Preliminary Research on a Novel Soil Improvement Technique by Microbial Denitrification. $\mathrm{PhD}$ thesis, Huazhong University of Science and Technology, Wuhan, China.

Farah T, Souli H, Fleureau JM et al. (2016) Durability of bioclogging treatment of soils. Journal of Geotechnical and Geoenvironmental Engineering 142(9): 04016040, https://doi.org/10.1061/(ASCE)GT. 1943-5606.0001503.

Feng K and Montoya BM (2016) Influence of confinement and cementation level on the behavior of microbial-induced calcite precipitated sands under monotonic drained loading. Journal of Geotechnical and Geoenvironmental Engineering 142(1): 04015057, https://doi.org/10.1061/(ASCE)GT.1943-5606.0001379.

Feng K and Montoya BM (2017) Quantifying level of microbial-induced cementation for cyclically loaded sand. Journal of Geotechnical and Geoenvironmental Engineering 143(6): 06017005, https://doi.org/10. 1061/(ASCE)GT.1943-5606.0001682.

Fujita Y, Taylor JL, Wendt LM, Reed DW and Smith RW (2010) Evaluating the potential of native ureolytic microbes to remediate a ${ }^{90} \mathrm{Sr}$ contaminated environment. Environmental Science \& Technology 44(19): 7652-7658, https://doi.org/10.1021/es101752p.

Glass C and Silverstein J (1998) Denitrification kinetics of high nitrate concentration water: $\mathrm{pH}$ effect on inhibition and nitrite accumulation Water Research 32(3): 831-839, https://doi.org/10.1016/S0043-1354 (97)00260-1.

Gomez MG, Anderson CM, Graddy CMR et al. (2017) Large-scale comparison of bioaugmentation and biostimulation approaches for biocementation of sands. Journal of Geotechnical and Geoenvironmental Engineering 143(5): 04016124, https://doi.org/10. 1061/(ASCE)GT.1943-5606.0001640.

Ham SM, Chang I, Noh DH, Kwon TH and Muhunthan B (2018) Improvement of surface erosion resistance of sand by microbial biopolymer formation. Journal of Geotechnical and Geoenvironmental
Engineering 144(7): 06018004, https://doi.org/10.1061/(ASCE)GT. 1943-5606.0001900.

Hamdan N and Kavazanjian EJ (2016) Enzyme-induced carbonate mineral precipitation for fugitive dust control. Géotechnique 66(7): 546-555, https://doi.org/10.1680/jgeot.15.P.168.

Han ZG, Cheng XH and Ma Q (2016) An experimental study on dynamic response for MICP strengthening liquefiable sands. Earthquake Engineering and Engineering Vibration 15(4): 673-679, https://doi. org/10.1007/s11803-016-0357-6.

Harkes MP, van Paassen LA, Booster JL, Whiffin VS and van Loosdrecht MCM (2010) Fixation and distribution of bacterial activity in sand to induce carbonate precipitation for ground reinforcement. Ecological Engineering 36(2): 112-117, https://doi.org/10.1016/j.ecoleng.2009. 01.004.

He J (2013) Mitigation of Liquefaction of Sand Using Microbial Methods. $\mathrm{PhD}$ thesis, Nanyang Technological University, Singapore.

He J and Chu J (2014) Undrained responses of microbially desaturated sand under monotonic loading. Journal of Geotechnical and Geoenvironmental Engineering 140(5): 04014003, https://doi.org/10. 1061/(ASCE)GT.1943-5606.0001082.

He J, Chu J and Ivanov V (2013) Mitigation of liquefaction of saturated sand using biogas. Géotechnique 63(4): 267-275, https://doi.org/10 1680/bcmpge.60531.011.

He J, Chu J and Liu H (2014) Undrained shear strength of desaturated loose sand under monotonic shearing. Soils and Foundations 54(4): 910-916, https://doi.org/10.1016/j.sandf.2014.06.020.

Ivanov V and Chu J (2008) Applications of microorganisms to geotechnical engineering for bioclogging and biocementation of soil in situ. Reviews in Environmental Science and Biotechnology 7(2): 139-153, https://doi.org/10.1007/s11157-007-9126-3.

Ivanov V, Chu J, Stabnikov V and Li B (2015) Strengthening of soft marine clay using bioencapsulation. Marine Georesources and Geotechnology 33(4): 320-324, https://doi.org/10.1080/1064119X.2013.877107.

James GA, Warwood BK, Hiebert R and Cunningham AB (2000) Microbial barriers to the spread of pollution. In Bioremediation (Valdes JJ (ed.)). Springer, Amsterdam, the Netherlands, pp. 1-13.

Jiang NJ and Soga K (2017) The applicability of microbially induced calcite precipitation (MICP) for internal erosion control in gravel-sand mixtures. Géotechnique 67(1): 42-55, https://doi.org/10.1680/jgeot.15. P.182.

Jiang NJ, Soga K and Dawoud O (2014) Experimental study of the mitigation of soil internal erosion by microbially induced calcite precipitation. In Geo-Congress 2014 Technical Papers: GeoCharacterization and Modeling for Sustainability (Abu-Farsakh M, Yu X and Hoyos LR (eds)). American Society of Civil Engineers, Reston, VA, USA, Geotechncial Special Publication no. 234, pp. 1586-1595. Jiang NJ, Yoshioka H, Yamamoto K and Soga K (2016) Ureolytic activities of a urease-producing bacterium and purified urease enzyme in the anoxic condition: implication for subseafloor sand production control by microbially induced carbonate precipitation (MICP). Ecological Engineering 90: 96-104, https://doi.org/10.1016/j.ecoleng. 2016.01.073.

Jiang NJ, Soga K and Kuo M (2017) Microbially induced carbonate precipitation for seepage-induced internal erosion control in sand-clay mixtures. Journal of Geotechnical and Geoenvironmental Engineering 143(3): 04016100, https://doi.org/10.1061/(ASCE)GT.1943-5606. 0001559.

Lambert JWM, Novakowski K, Blauw M et al. (2010) Pamper bacteria, they will help us: application of biochemical mechanisms in geoenvironmental engineering. In GeoFlorida 2010: Advances in Analysis, Modeling \& Design (Fratta DO, Puppala AJ and Muhunthan B (eds)). American Society of Civil Engineers, Reston, VA, USA, Geotechncial Special Publication no. 199, pp. 618-627.

Li B (2015) Geotechnical Properties of Biocement Treated Soils. PhD thesis, Nanyang Technological University, Singapore. 
Li M, Cheng X and Guo H (2013a) Heavy metal removal by biomineralization of urease producing bacteria isolated from soil. International Biodeterioration \& Biodegradation 76: 81-85, https:// doi.org/10.1016/j.ibiod.2012.06.016.

Li M, Guo HX and Cheng XH (2013b) Isolation of urease producing bacteria from soil and its mineralization on heavy metal, Hubei, China. Agricultural Sciences 52(14): 3280-3282, https://doi.org/10.1016/j. ibiod.2012.06.016.

Li B, Chu J and Whittle A (2016) Biotreatment of fine-grained soil through the bioencapsulation method. In Geo-Chicago 2016: Sustainability and Resiliency in Geotechnical Engineering (Zekkos D, Farid A, De A, Reddy KR and Yesiller N (eds)). American Society of Civil Engineers, Reston, VA, USA, pp. 25-32.

Lin H, Suleiman MT, Brown DG and Kavazanjian E (2016) Mechanical behavior of sands treated by microbially induced carbonate precipitation. Journal of Geotechnical and Geoenvironmental Engineering 142(2): 04015066, https://doi.org/10.1061/(ASCE)GT. 1943-5606.0001383.

Lu ZW, Qian CX and Xu YB (2012) Study and comparison of mineralized consolidation $\mathrm{Zn}^{2+}$ between bacteria and powder, China. Environmental Science and Technology 35(12J): 58-61.

Mahawish A, Bouazza A and Gates WP (2016) Biogrouting coarse materials using soil-lift treatment strategy. Canadian Geotechnical Journal 53(12): 2080-2085, https://doi.org/10.1139/cgj-2016-0167.

Mahawish A, Bouazza A and Gates WP (2018) Effect of particle size distribution on the bio-cementation of coarse aggregates. Acta Geotechnica 13(4): 1019-1025, https://doi.org/10.1007/s11440-017-0604-7.

Mani D and Chitranjan K (2014) Biotechnological advances in bioremediation of heavy metals contaminated ecosystems: an overview with special reference to phytoremediation. International Journal of Environmental Science and Technology 11(3): 843-872, https://doi. org/10.1007/s13762-013-0299-8.

Manning DAC (2008) Biological enhancement of soil carbonate precipitation: passive removal of atmospheric $\mathrm{CO}_{2}$. Mineralogical Magazine 72(2): 639-649, https://doi.org/10.1180/minmag.2008.072.2. 639.

Martinez BC, DeJong JT, Ginn TR et al. (2013) Experimental optimization of microbial induced carbonate precipitation for soil improvement. Journal of Geotechnical and Geoenvironmental Engineering 139(4): 587-598, https://doi.org/10.1061/(ASCE)GT.1943-5606.0000787.

Maryam N (2014) Biocementation of Sand in Geotechnical Engineering. $\mathrm{PhD}$ thesis, Nanyang Technological University, Singapore.

Mitchell J and Santamarina J (2005) Biological considerations in geotechnical engineering. Journal of Geotechnical and Geoenvironmental Engineering 131(10): 1222-1233, https://doi.org/ 10.1061/(ASCE)1090-0241(2005)131:10(1222).

Montaya BM, DeJong JT and Boulanger RW (2013) Dynamic response of liquefiable sand improved by microbial-induced calcite precipitation. Géotechnique 63(4): 302-312, https://doi.org/10.1680/geot.SIP13.P. 019.

Montoya BM and DeJong JT (2015) Stress-strain behavior of sands cemented by microbially induced calcite precipitation. Journal of Geotechnical and Geoenvironmental Engineering 141(6): 04015019, https://doi.org/10.1061/(ASCE)GT.1943-5606.0001302.

Neupane D, Yasuhara H, Kinoshita N and Unno T (2013) Applicability of enzymatic calcium carbonate precipitation as a soil-strengthening technique. Journal of Geotechnical and Geoenvironmental Engineering 139(12): 2201-2211, https://doi.org/10.1061/(ASCE)GT.1943-5606. 0000959 .

Neupane D, Yasuhara H, Kinoshita N and Ando Y (2015a) Distribution of mineralized carbonate and its quantification method in enzyme mediated calcite precipitation technique. Soils and Foundations 55(2): 447-457, https://doi.org/10.1016/j.sandf.2015.02.018.

Neupane D, Yasuhara H, Kinoshita N and Putra H (2015b) Distribution of grout material within 1-m sand column in insitu calcite precipitation technique. Soils and Foundations 55(6): 1512-1518, https://doi.org/10. 1016/j.sandf.2015.10.015.

O'Donnell ST and Kavazanjian E (2015) Stiffness and dilatancy improvements in uncemented sands treated through MICP. Journal of Geotechnical and Geoenvironmental Engineering 141(11): 02815004 https://doi.org/10.1061/(ASCE)GT.1943-5606.0001407.

O'Donnell ST, Rittmann BE and Kavazanjian E Jr (2017a) MIDP: liquefaction mitigation via microbial denitrification as a two-stage process: I: desaturation. Journal of Geotechnical and Geoenvironmental Engineering 143(12): 04017094, https://doi.org/10. 1061/(ASCE)GT.1943-5606.0001818.

O'Donnell ST, Kavazanjian E Jr and Rittmann BE (2017b) MIDP: liquefaction mitigation via microbial denitrification as a two-stage process: II: MICP. Journal of Geotechnical and Geoenvironmental Engineering 143(12): 04017095, https://doi.org/10.1061/(ASCE)GT. 1943-5606.0001806.

Okamura M and Soga Y (2006) Effects of pore fluid compressibility on liquefaction resistance of partially saturated sand. Soils and Foundations 46(5): 695-700, https://doi.org/10.3208/sandf.46.695.

Okamura M, Takebayashi M, Nishida K et al. (2011) In-situ desaturation test by air injection and its evaluation through field monitoring and multiphase flow simulation. Journal of Geotechnical and Geoenvironmental Engineering 137(7): 643-652, https://doi.org/10. 1061/(ASCE)GT.1943-5606.0000483.

Phillips AJ, Lauchnor E, Eldring J et al. (2013) Potential $\mathrm{CO}_{2}$ leakage reduction through biofilm-induced calcium carbonate precipitation. Environmental Science \& Technology 47(1): 142-149, https://doi.org/ 10.1021/es301294q

Proto CJ, DeJong JT and Nelson DC (2016) Biomediated permeability reduction of saturated sands. Journal of Geotechnical and Geoenvironmental Engineering 142(12): 04016073, https://doi.org/10. 1061/(ASCE)GT.1943-5606.0001558.

Qian CX, Xu YB, Hu LM and Hu ZW (2011) Study on $\mathrm{Cu}^{2+}$ in contaminated system mineralized by bacteria, China. Environmental Science \& Technology 34(12H): 33-36.

Rebata-Landa V and Santamarina JC (2012) Mechanical effects of biogenic nitrogen gas bubbles in soils. Journal of Geotechnical and Geoenvironmental Engineering 138(2): 128-137, https://doi.org/10. 1061/(ASCE)GT.1943-5606.0000571.

Rong H, Qian CX and Li LZ (2013) Cementation mechanism of microbe cement, China. Journal of the Chinese Ceramic Society 41(3): 314-319.

Saleh-Lakha S, Shannon KE, Henderson SL et al. (2009) Effect of pH and temperature on denitrification gene expression and activity in Pseudomonas mandelii. Applied and Environmental Microbiology 75(12): 3903-3911, https://doi.org/10.1128/AEM.00080-09.

Sasaki T and Kuwano R (2016) Undrained cyclic triaxial testing on sand with non-plastic fines content cemented with microbially induced $\mathrm{CaCO}_{3}$. Soils Found 56(3): 485-495, https://doi.org/10.1016/j.sandf.2016.04.014.

Seki K, Miyazaki T and Nakano M (1998) Effects of microorganisms on hydraulic conductivity decrease in infiltration. European Journal of Soil Science 49(2): 231-236, https://doi.org/10.1046/j.1365-2389. 1998.00152.x.

Simatupang M and Okamura M (2017) Liquefaction resistance of sand remediated with carbonate precipitation at different degrees of saturation during curing. Soils and Foundations 57(4): 619-631, https://doi.org/10.1016/j.sandf.2017.04.003.

Simek M, Jisova L and Hopkins DW (2002) What is the so-called optimum $\mathrm{pH}$ for denitrification in soil? Soil Biology and Biochemistry 34(9): 1227-1234, https://doi.org/10.1016/S0038-0717(02)00059-7.

Soon N, Lee L, Khun T and Lin HS (2014) Factors affecting improvement in engineering properties of residual soil through microbial-induced calcite precipitation. Journal of Geotechnical and Geoenvironmental Engineering 140(5): 04014006, https://doi.org/10.1061/(ASCE)GT. 1943-5606.0001089. 
Stabnikov V, Chu J, Ivanov V and Li YS (2013) Halotolerant, alkalophilic urease-producing bacteria from different climate zones and their application for biocementation of sand. World Journal of Microbiology and Biotechnology 29(8): 1453-1460, https://doi.org/10.1007/s11274013-1309-1.

Stanford G, Dzienia S and Vanderpol RA (1975) Effect of temperature on denitrification rate in soils. Soil Science Society of America Journal 39(5): $867-870$.

Tang Q, Gu F, Zhang Y, Zhang YQ and Mo JL (2018) Impact of biological clogging on the barrier performance of landfill liners. Journal of Environmental Management 222: 44-53, https://doi.org/10.1016/j. jenvman.2018.05.039.

Thullner M (2010) Comparison of bioclogging effects in saturated porous media within one- and two-dimensional flow systems. Ecological Engineering 36(2): 176-196, https://doi.org/10.1016/j.ecoleng.2008. 12.037 .

Tsukamoto Y, Ishihara K, Nakazawa H, Kamada K and Huang YN (2002) Resistance of partly saturated sand to liquefaction with reference to longitudinal and shear wave velocities. Soils and Foundations 42(6): 93-104, https://doi.org/10.3208/sandf.42.6 93.

van Meurs G, van der Zon W, Lambert J and van Ree CCDF (2006) The challenge to adapt soil properties. In 5th ICEG Environmental Geotechnics: Opportunities, Challenges and Responsibilities for Environmental Geotechnics (Thomas HR (ed.)). ICE Publishing, London, UK, pp. 1192-1199.

van Paassen LA (2011) Bio-mediated ground improvement: from laboratory experiment to pilot applications. In Proceedings of GeoFrontiers 2011: Advances in Geotechnical Engineering (Han J and Alzamora DE (eds)). American Society of Civil Engineers, Reston, VA, USA, pp. 4099-4108.

van Paassen LA, Harkes MP, Van Zwieten GA et al. (2009) Scale up of BioGrout: a biological ground reinforcement method. In Proceedings of the 17th International Conference on Soil Mechanics and Geotechnical Engineering: the Academia and Practice of Geotechnical Engineering (Hamza M, Shahien M and ElMossallamy Y (eds)). IOS Press, Amsterdam, the Netherlands, pp. 2328-2333.

van Paassen LA, Ghose R, Van Der Linden TJM, van der Star WRL and van Loosdrecht MCM (2010a) Quantifying biomediated ground improvement by ureolysis: large-scale biogrout experiment. Journal of Geotechnical and Geoenvironmental Engineering 136(12): 1721-1728, https://doi.org/10.1061/(ASCE)GT.1943-5606.0000382. van Paassen LA, Daza CM, Staal M et al. (2010b) Potential soil reinforcement by biological denitrification. Ecological Engineering 36(2): 168-175, https://doi.org/10.1016/j.ecoleng.2009.03.026.

Wang RX, Qian CX, Wu M and Cheng L (2007) Study on heavy metal removal in soil mineralized by bacteria, China. Functional Materials 38(9): 1523-1526.

Warthmann R, Van Lith Y, Vasconcelos C, McKenzie JA and Karpoff AM (2000) Bacterially induced dolomite precipitation in anoxic culture experiments. Geology 28(12): 1091-1094, https://doi.org/10.1130/ 0091-7613(2000)28<1091:BIDPIA >2.0.CO;2.

Weaver T, Burbank M, Lewis A and Lewis R (2011) Bio-induced calcite, iron, and manganese precipitation for geotechnical engineering applications. In Proceedings of Geo-Frontiers 2011: Advances in Geotechnical Engineering (Han J and Alzamora DE (eds)). American Society of Civil Engineers, Reston, VA, USA, pp. 3975-3983.

Whiffin VS, van Paassen LA and Harkes MP (2007) Microbial carbonate precipitation as a soil improvement technique. Geomicrobiology Journal 24(5): 417-423, https://doi.org/10.1080/01490450701436505.

Xu YB, Qian CX and Lu ZW (2012) Study on $\mathrm{Pb}^{2+}$ mineralized by bacteria for remediation, China. Chemical Industry Times 26(6): 14-17.

Xu YB, Qian CX and Lu ZW (2013) Remediation of heavy metal contaminated soils by bacteria biomineralization, China. Chinese Journal of Environmental Engineering 7(7): 2763-2768.

Yang J, Savidis S and Roemer M (2004) Evaluating liquefaction strength of partially saturated sand. Journal of Geotechnical and Geoenvironmental Engineering 130(9): 975-979, https://doi.org/10. 1061/(ASCE)1090-0241(2004)130:9(975).

Yegian M, Eseller-Bayat E, Alshawabkeh A and Ali S (2007) Induced-partial saturation for liquefaction mitigation: experimental investigation. Journal of Geotechnical and Geoenvironmental Engineering 133(4): 372-380, https://doi.org/10.1061/(ASCE)1090-0241(2007)133:4(372).

Zamani A and Montoya BM (2018) Undrained monotonic shear response of MICP-treated silty sands. Journal of Geotechnical and Geoenvironmental Engineering 144(6): 04018029, https://doi.org/10. 1061/(ASCE)GT.1943-5606.0001861.

Zhao Q (2014) Experimental Study on Soil Improvement Using Microbial Induced Calcite Precipitation. $\mathrm{PhD}$ thesis, China University of Geosciences, Beijing, China.

Zhao Q, Li L, Li C et al. (2014) Factors affecting improvement of engineering properties of MICP-treated soil catalyzed by bacteria and urease. Journal of Materials in Civil Engineering 26(12): 04014094, https://doi.org/10.1061/(ASCE)MT.1943-5533.0001013.

\section{How can you contribute?}

To discuss this paper, please submit up to 500 words to the editor at journals@ice.org.uk. Your contribution will be forwarded to the author(s) for a reply and, if considered appropriate by the editorial board, it will be published as a discussion in a future issue of the journal. 